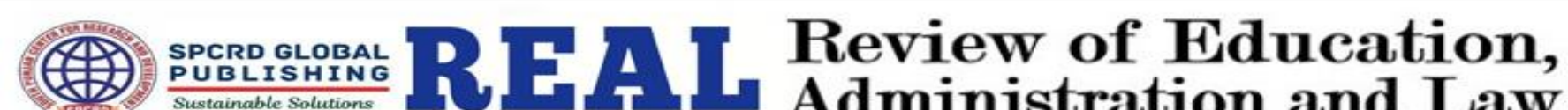 \\ Journal homepage: http://real.spcrd.org ISSN (Print): 2708-1788 ISSN (Online): 2708-3667
}

\section{Preparedness of Prospective Teachers for Inclusive Education: Pre-Service Teachers' Knowledge and Skills}

\author{
${ }^{a}$ Shaheen Pasha, ${ }^{\mathrm{b}}$ Farzana Yousaf, ${ }^{\mathrm{c}}$ Maimona Ijaz \\ ${ }^{a}$ Chairperson/Assistant Professor, Department of Special Education (DOE), University of Education, Lahore, \\ Pakistan \\ Email: drshaheen.pasha@ue.edu.pk \\ ${ }^{\mathrm{b}}$ Lecturer, University of Education, Lahore, Pakistan \\ Email: farzana.yousaf@ue.edu.pk \\ ${ }^{\mathrm{c}}$ M.Phil. Special Education, Visiting Faculty Member, Department of Special Education, University of Education, \\ Lahore, Pakistan \\ Email: fnm.international@gmail.com
}

\begin{tabular}{|c|c|}
\hline ARTICLE DETAILS & \multirow{10}{*}{$\begin{array}{l}\text { ABSTRACT } \\
\text { The inclusion of students with special needs in regular schools is now } \\
\text { one of the most important international and national issues faced by the } \\
\text { educational world. The study examined concepts of prospective teachers } \\
\text { about inclusion, skill, and knowledge gained through these educational } \\
\text { programs. This was quantitative research conducted by using a } \\
\text { descriptive survey. The questionnaire is designed by the researcher } \\
\text { based on objective, theoretical framework, and literature review of } \\
\text { related studies. Responses to the survey were obtained from } 250 \text { pre- } \\
\text { service teachers. It indicated that the majorities of pre-service teachers } \\
\text { have concept clarity about inclusion and prepare to implement the skill, } \\
\text { and knowledge gained through these educational programs. This } \\
\text { research is a small effort from the platform of special education to } \\
\text { collaborate with general education for the promotion of inclusion of } \\
\text { these children in society by using the means of inclusive teacher } \\
\text { education programs. This study provides a useful paradigm for future } \\
\text { research in this field. }\end{array}$} \\
\hline History: & \\
\hline 20 April 2021 & \\
\hline Available Online June 2021 & \\
\hline Keywords: & \\
\hline Inclusive Education, Teacher & \\
\hline $\begin{array}{l}\text { Education, Pre-Service } \\
\text { Knowledge, Skills }\end{array}$ & \\
\hline JEL Classification: & \\
\hline$P_{36}, I_{21}$ & \\
\hline DOI: $10.47067 /$ real.v4i2.148 & \\
\hline
\end{tabular}

(C) 2021 The authors. Published by SPCRD Global Publishing. This is an open access article under the Creative Commons AttributionNonCommercial 4.0

Corresponding author's email address: drshaheen.pasha@ue.edu.pk

\section{Introduction}

Globally, inclusive education has a remarkable effect on researches, policies, and execution in the field of education. As inclusive education remains under great debate for its definition, perception, and practices all over the world so this idea does not merely include special needs, children in regular schools but the inclusion of all children irrespective of age, ethnicity, culture, gender, race, linguistic, social or economic status or any health condition. This comprehensive interpretation of inclusive education has a great effect on the conversion of the whole education system (Winter, 2006). 
Teacher Education relates to policy and procedures to provide future teachers with the information, attitudes, actions, and skills required for the effective execution of their roles in the classroom, school, and in the broader community. Teacher education is a teacher training system that focuses on the teaching of teachers and expertise, which encourages and empowers teachers to address the needs of their profession. (Kapur, 2018)

Inclusion in education also ensures that every pupil has a right to education. According to Booth (2011), The concept of inclusion has ties to the philosophy of engagement and is focused on collaboration, involvement, democratization, advantage equal opportunities, consistency, justice, and fairness. Inclusion requires the involvement and support of all pupils in the school environment and curriculum (Haug, 2017).

Researches from both North and South of the World Global have recognized that teachers become central players for the successful application of inclusive education policy so the teacher has the most accountability for the students and their everyday learning process(Avramidis \& Norwich, 2002; Swart, Engelbrecht, Eloff, \& Pettipher, 2002) When schools continue to pursue a more holistic method to teaching students of different backgrounds and educational needs, attention is given to how instructors are trained for inclusive teaching practices. Educational inclusion is the educational method by which all children are learning collectively, irrespective of race, gender, faith, learning needs of the individuals, and martial and social backgrounds of the same classroom(Massouti, 2019).

Studies on inclusive education had revealed that the majority of studies centered on the instructional abilities of pre-service teachers to support special needs children (McCray \& McHatton, 2011; Rose \& Garner, 2010; Wang \& Fitch, 2010). Many research explored how pre-service teacher mindset and values affect their future educational activities to provide students with exceptional students. The studies examined the execution of inclusive education policies at schools, the implementation of teacher education for inclusion through programs of study and practice, and how future teachers should be encouraged to implement inclusive educational practices reflecting awareness of the various crucial aspects of inclusiveness. The research studies were chosen for the analysis centered on teacher education in inclusive learning, on how inclusion and their strategies are applied in classrooms, on inclusive curricula and teacher education activities, and on promoting strong values and integration attitudes among future teachers. .(Hamilton-Jones \& Vail, 2014; Loreman, 2010; Sharma, 2010; Sharma, Forlin, \& Loreman, 2008; Sharma \& Sokal, 2016; Specht, 2016)

The main objective of the study is to examine concepts of prospective teachers about inclusion, skill, and knowledge gained through these pre-service education programs.

\section{Literature review}

Studies on inclusive education had revealed that the majority of studies centered on the instructional abilities of pre-service teachers to support special needs children (McCray \& McHatton, 2011; Rose \& Garner, 2010; Wang \& Fitch, 2010). Many research explored how pre-service teacher mindset and values affect their future educational activities to provide students with exceptional students. The studies examined the execution of inclusive education policies at schools, the implementation of teacher education for inclusion through programs of study and practice, and how future teachers should be encouraged to implement inclusive educational practices reflecting awareness of the various crucial aspects of inclusiveness. The research studies were chosen for the analysis centered on teacher education in inclusive learning, on how inclusion and their strategies are applied in classrooms, on inclusive curricula and teacher education activities, and on promoting strong values and 
integration attitudes among future teachers. .(Hamilton-Jones \& Vail, 2014; Loreman, 2010; Sharma, 2010; Sharma, Forlin, \& Loreman, 2008; Sharma \& Sokal, 2016; Specht, 2016)

The goal for pre-service teacher education is to provide educators with the correct behaviors, expertise, specialist knowledge, and skills to execute inclusive education policies effectively. Many research showed that teacher education before service has a beneficial effect on enhancing instructor pre-service understanding and attitudes regarding disabilities, skills, and training approaches in inclusive contexts (Nketsia, 2017)

Many international publications have underlined this important role, for example in the UNESCO guidelines on inclusion in education, the World Report on Disability (WHO, 2011), and the United Nations Standard Rules on Equalization of Opportunities for Disabled persons(UNESCO, 1990). Together, these agreements focused upon the incorporation of inclusive strategies and resources to provide teachers with appropriate skills, information, attitudes, and pedagogical capacity, to teach and adapt to the diverse learning conditions of various classes of students through pre-and in-service teacher education programs.

Investing in high-quality teacher training is critical for the comprehensive improvement of education. The performance of effective classrooms relies on competent, productive, and optimistic teachers who agree that all children can learn in the same classroom (Killoran et al., 2014; Peebles \& Mendaglio, 2014). Evidence has shown that pre-service curriculum should include the practical experience in ' actual environments ' for the schooling of several groups of adolescents, including the disadvantaged, and promote activities which have proved effective in comprehensive educational settings such as cooperative instruction, co-teaching by peer (Tahsein \& Ahsan, 2016).

Although inclusive education seeks to accept schools for all pupils regardless of their ability or context, teachers are more uncomfortable and lack confidence in the inclusion of disabled children in their teacher training programs, however, special attention should be paid to addressing problems associated with disabilities. Although many investigators have written that teachers are not prepared for inclusive learning in developing countries, there are few pieces of research on challenges that are confronted and how these challenges are tackled(Florian \& Rouse, 2009).

Several features have been identified as insufficient in other pre-service educator programs. One key issue of pre-service teacher education was the research carried out in India and Hong Kong have described the worries of teachers about the lack of support for services during their pre-service schooling (Sharma, Moore, \& Sonawane, 2009; Stella, Forlin, \& Lan, 2007), Several reports (also indicated that shorter preparation periods are difficult to properly educate pre-service educators. Researches in countries such as India, Hong Kong, and South Africa, have shown various difficulties particularly related to socio-cultural contexts for the introduction of inclusive education(Ahsan, Sharma, \& Deppeler, 2012a).

Research by Singal (2005) showed that the difficulties of adopting inclusive education included negative attitudes, contradictory values, the fragmented or undefined conceptualization of interaction between teacher educators, limited resources, and insufficient training for teachers. Other Indian research showed that the key obstacles to introducing inclusive education have been the lack of equipment, negative positions, and poor teacher readiness. These problems have also been found in other Asia-Pacific countries (Stites et al., 2018). 
Work carried out in countries such as the USA and Hong Kong shows that teachers participating in pre-school classroom preparation are low in confidence and use program frameworks and teaching methods that do not allow self-sustaining pre-school teachers for inclusive education. Angelides, Stylianou, and Gibbs (2006) and Harvey, Yssel, Bauserman, and Merbler (2010) both say that there is an inadequate practical experience for pre-service instructors.

Many interlocutors felt that teachers were qualified to perform inclusive teaching, but claimed that teachers had to be properly prepared. We became concerned about the fact that current teacher preparation pre-service was not suitable for effective teacher training. Different subjects came in the fields of education, which included learning problems, teacher training, curriculum, class sizes(Ahsan et al., 2013).

Studies indicate a persistent lack of insight into teachers ' understanding of best practices (Kilanowski-Press, Foote, \& Rinaldo, 2010) Many studies indicate that a shortage of encouragement as a challenge to effective inclusive teaching has been identified by teachers. Teachers also recorded being solely responsible in the context of their classes for delivering high-quality, inclusive support Policing and the culture of Schools have also been seen as obstacles to successful inclusion practices(Kraska \& Boyle, 2014; Muccio, Kidd, White, \& Burns, 2014; Wright, 2016)

Research has also shown that teachers ' expectations of equal teaching, including years of experience and sex, are influenced by social differences. Class sizes, impairment frequency, student attitude, degree level, and instructor knowledge are specifically cited as an impairment to inclusion. Proper awareness, teaching, preparation, and program modifications lead to increased confidence and constructive outcomes and behaviors in the area of inclusive education(Wright, 2016).

However, previous pedagogical contact with SEN students could have a positive impact on pupils ' inclusiveness and can allow teachers to feel more comfortable in their learning (Tsakiridou \& Polyzopoulou, 2014). The well-developed program, better training on special education, coordination between all partners, modern orientated approaches of learning, and properly planned field interactions are very key factors that affect teachers ' self-efficacy and trust and shape supportive teaching perceptions towards inclusive education (Pappas, Papoutsi, \& Drigas, 2018).

\section{Research Design and Instrumentation}

The study was quantitative; a survey was conducted while using a five-point liker scale questionnaire. The participant of the study was Pre-service teachers enrolled in teacher education programs at three universities of Lahore. The survey was obtained from 270 pre-service teachers. The random sampling technique was used while selecting samples. The questionnaire is designed by the researcher under the supervision of the supervisor based on objective, theoretical framework, and literature review and validated by the expert of the fields. and have statements 


\section{Results}

\section{Demographical information}

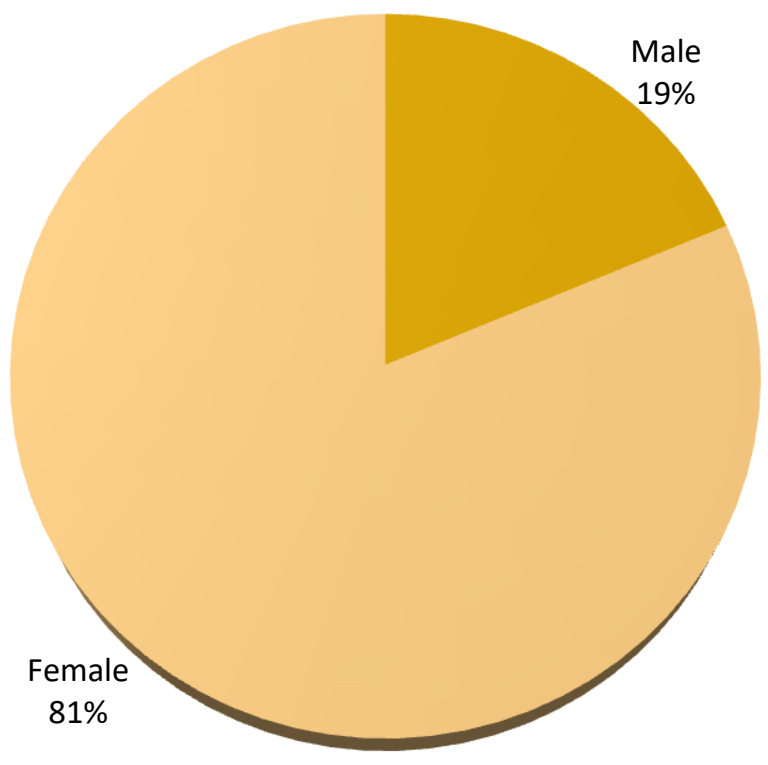

Figure 1: Gender ratio of the pre-service teachers



Figure 2: Professional Qualification ratio of the pre-service teacher 


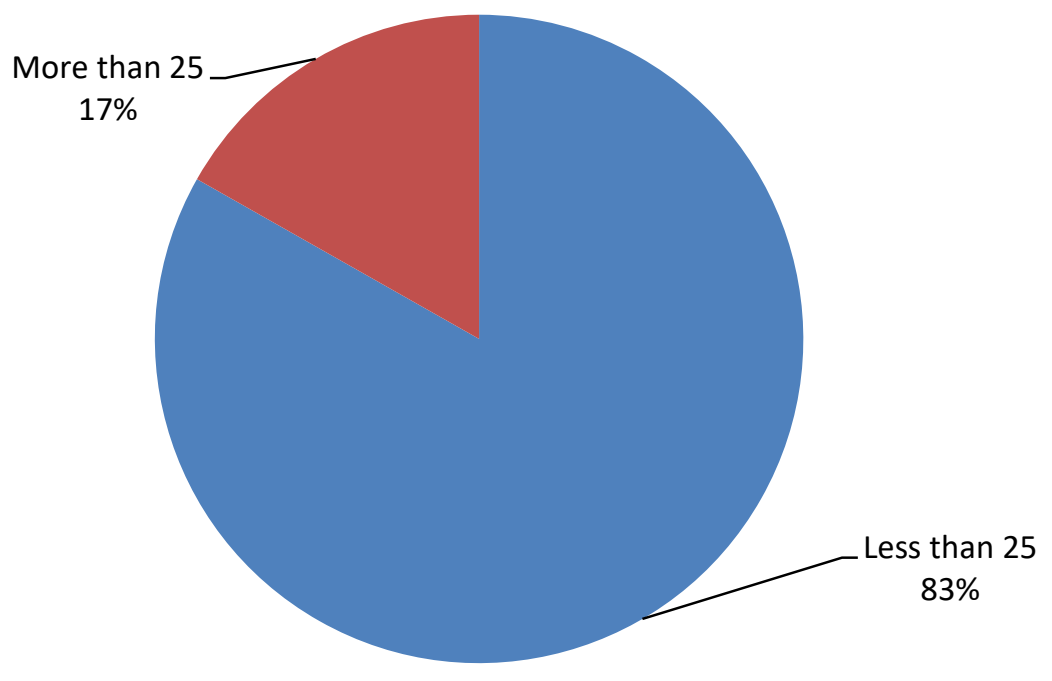

Figure 3: Age ratio of the pre-service teachers

Table: 1 Descriptive statistics of responses regarding knowledge of preservice teacher about inclusive education

\begin{tabular}{|l|l|l|}
\hline Items & M & SD \\
\hline $\begin{array}{l}\text { 1. I have clear concepts of the term “Inclusion". } \\
\text { 2. Every child regardless of disabilities has the right to be } \\
\text { educated in the regular class. }\end{array}$ & 3.7 & 1.258 \\
\hline $\begin{array}{l}\text { 3. Students with special needs can best be served in the general } \\
\text { education classroom. }\end{array}$ & 3.60 & 1.261 \\
\hline $\begin{array}{l}\text { 4. The inclusion of students with special needs in the class can } \\
\text { be beneficial for students without disabilities. }\end{array}$ & & 1.226 \\
\hline $\begin{array}{l}\text { 5. Students with special needs benefit both academically and } \\
\text { socially from being placed in an inclusive setting. }\end{array}$ & 3.48 & 1.212 \\
\hline $\begin{array}{l}\text { 6. Inclusive teaching is a successful education system to } \\
\text { address learners' needs. }\end{array}$ & 3.67 & 1.15 \\
\hline $\begin{array}{l}\text { 7. Inclusive teaching requires collaboration among teachers } \\
\text { (General \&special). }\end{array}$ & 3.74 & 1.142 \\
\hline $\begin{array}{l}\text { 8. Successful implementation of inclusive education requires } \\
\text { special training for teachers. }\end{array}$ & 3.74 & 1.283 \\
\hline $\begin{array}{l}\text { 9. Teachers should use different methods of teaching to satisfy } \\
\text { the needs of disabled students. }\end{array}$ & 4.06 & 1.218 \\
\hline $\begin{array}{l}\text { 10. Teachers should have opportunities to adapt the syllabus } \\
\text { and teaching materials while teaching in inclusive classes. }\end{array}$ & 3.88 & $\mathbf{1 . 1 1 8}$ \\
\hline $\begin{array}{l}\text { 11. The teacher should encourage cooperative learning to make } \\
\text { all students support each other. }\end{array}$ & 3.86 & 1.331 \\
\hline
\end{tabular}


12. The teacher must design the individualized education plan (IEP) for children with special needs.

13. Inclusive teaching makes the teacher feel more responsible for students with special needs.

14. Teacher should manage the classroom layout and setting plan for the children with special needs.

15. Teachers should use differentiated instruction in an inclusive classroom.

16. Teachers should collaborate with other professionals in designing individualized educational plans (IEP) for students with disabilities.

17. Teaching strategies (Task Analysis, shaping, Chaining Prompting, Fading) should use in an inclusive classroom.

The means of 17 items are shown in Table 1 regarding the knowledge of preservice teachers about inclusive education. All items have a mean score above 3.50.

Table: 2 Descriptive statistics of responses regarding the skill of preservice teacher about inclusive education

\begin{tabular}{|l|l|l|}
\hline \multicolumn{1}{|c|}{ Items } & M & SD \\
\hline $\begin{array}{l}\text { 18. I can use different approaches (e.g. Response to intervention } \\
\text { \& inquiry-based learning) for the support of students with } \\
\text { diverse learning needs. }\end{array}$ & 3.79 & 1.091 \\
\hline $\begin{array}{l}\text { 19. I am prepared to use reinforcement strategies in an inclusive } \\
\text { classroom. }\end{array}$ & 3.61 & 1.097 \\
\hline $\begin{array}{l}\text { 20. I can provide an alternate explanation for example when } \\
\text { students are confused. }\end{array}$ & 3.73 & 1.197 \\
\hline $\begin{array}{l}\text { 21. I am confident in designing learning tasks for the individual } \\
\text { needs of students with disabilities. }\end{array}$ & 3.72 & 1.174 \\
\hline $\begin{array}{l}\text { 22. I can use a variety of assessment strategies (e.g., portfolio, } \\
\text { assessment, modified tests, performance-based assessment, } \\
\text { etc.). }\end{array}$ & & \\
\hline $\begin{array}{l}\text { 23. I am prepared to deal with students who are behavioral } \\
\text { problems in an inclusive classroom. }\end{array}$ & 3.73 & 1.182 \\
\hline $\begin{array}{l}\text { 24. I am confident in my ability to get students to work together } \\
\text { in pairs or small groups with peers. }\end{array}$ & 3.75 & 1.195 \\
\hline
\end{tabular}

The means of 18 to 24 items are shown in Table 2 regarding the skills of preservice teachers about inclusive education. All items have a mean score above 3.50. The finding of the study showed that there was a strong, positive correlation between factors of pre-service education for the inclusion of children with special needs. It indicated that the majority of pre-service teachers had concept clarity about inclusion and prepares to implement the skill, and knowledge gained through these educational programs. 


\section{Discussion}

Undoubtedly teacher education is a key aspect in the process of developing and training teachers so that they are well prepared and practically trained to cater to the classroom of diverse populated students. Moreover, one of the major factors for successful inclusive practices across the globe is wellequipped teachers which are the ultimate product of an effective teacher program. (Taweechaisupapong, 2015)

The findings of the study supported by other researchers (Harvey et al., 2010) say that training for successful co-teaching in comprehensive classrooms by pre-service teachers allows both regular teachers and special teachers to grow and improve together, thereby improving the quality of the education for all learners.

Many research explored how pre-service teacher mindset and values affect their future educational activities to provide students with exceptional students(Hamilton-Jones \& Vail, 2014; Loreman, 2010; Sharma, 2010; Sharma et al., 2008; Sharma \& Sokal, 2016; Specht, 2016)

Professional experience remains a leading method for the preparation of teachers for inclusive education, while university lecturers and program planners have been granted more recognition for preparing prospective teachers for inclusive education (T. R. Van Laarhoven, Munk, Lynch, Bosma, \& Rouse, 2007). When students join the teaching profession willingly and enthusiastically in inclusive classes, it will undoubtedly lead to greater use of inclusive methods and the continuity of these good practices for the whole of their careers A teaching stage before service can be the best time to promote positive positions and build trust by delivering high-quality training. (Hemmings \& Woodcock, 2011; Woodcock, Hemmings, \& Kay, 2012) (Gupta \& Tandon, 2018). A shift from special training to inclusive learning implies that established in a variety of pre teachers ' courses and education systems is a challenge. Many improvements are needed including new courses with different curricula and titles, new forms of teaching and learning structure to break down obstacles for special children(Booth, Nes, \& Strømstad, 2003).

\section{Recommendation}

Indeed well-trained teachers are required for effective and quality education for all learners yet their inadequacy in many areas of quality improvement one of them is teacher education. To achieve Millennium Development Goals' second target of universal primary education it was recommended that effective teacher training and is necessary. This research is a small effort from the platform of special education to collaborate with general education for the promotion of inclusion of these children in society by using the means of inclusive teacher education programs. This study provides a useful paradigm for future research in this field.

\section{References}

Anderson, J., \& Boyle, C. (2015). Inclusive education in A ustralia: rhetoric, reality and the road ahead. Support for learning, 30(1), 4-22.

Angelides, P., Stylianou, T., \& Gibbs, P. (2006). Preparing teachers for inclusive education in Cyprus. Teaching and Teacher Education, 22(4), 513-522.

Arthur-Kelly, M., Sutherland, D., Lyons, G., Macfarlane, S., \& Foreman, P. (2013). Reflections on enhancing pre-service teacher education programmes to support inclusion: perspectives from New Zealand and Australia. European Journal of Special Needs Education, 28(2), 217-233.

Behlol, M. G. (2011). Inclusive education: Preparation of teachers, challenges in classroom and future 
prospects. Pakistan Journal of Education, 28(2), 63-73.

Bélanger, N., \& Gougeon, N. A. (2009). Inclusion on the agenda in four different school contexts in Canada (Ontario, Manitoba, New Brunswick and Québec). Research in Comparative and International Education, 4(3), 289-304.

Booth, T. (2011). The name of the rose: Inclusive values into action in teacher education. Prospects, 41(3), 303.

Booth, T., \& Ainscow, M. (2016). The Index for Inclusion: A Guide to School Development Led by Inclusive Values: Index for Inclusion Network.

York: Routledge Falmer).

Cologon, K. (2013). Inclusion in education: Towards equality for students with disability.

COOPERATION, O. F. E., \& DEVELOPMENT. (2017). Education at a glance 2017: OECD indicators: OECD.

Copeland, S. R., Keefe, E. B., Calhoon, A. J., Tanner, W., \& Park, S. (2011). Preparing teachers to provide literacy instruction to all students: Faculty experiences and perceptions. Research and Practice for Persons with Severe Disabilities, 36(3-4), 126-141.

Crocker, R., \& Dibbon, D. (2008). Teacher Education in Canada. Society for the Advancement of Excellence in Education.

Darling-Hammond, L. (2006). Constructing 21st-century teacher education. Journal of teacher education, 57(3), 300-314.

De Boer, A., Pijl, S. J., \& Minnaert, A. (2011). Regular primary schoolteachers' attitudes towards inclusive education: A review of the literature. International Journal of Inclusive Education, 15(3), 331-353.

DeLuca, C. (2012). Selecting inclusive teacher candidates: Validity and reliability issues in admission policy and practice. Teacher Education Quarterly, 39(4), 7-31.

skay, M., Onu, V., Ugwuanyi, L., Obiyo, N., \& Udaya, J. (2012). Preparing Teachers for Special Education in the United States: A Reflection. Online Submission.

Taweechaisupapong, M. (2015). Teachers views about teacher training towards inclusive education

(Master's thesis)

Thakur, I., \& Abbas, F. (2017). Inclusive Education in Punjab: Challenges and Way Forward. Journal of Inclusive Education, 1(1), 15-26.

Theoharis, G., \& Causton-Theoharis, J. (2011). Preparing pre-service teachers for inclusive classrooms: revising lesson-planning expectations. International Journal of Inclusive Education, 15(7), 743761.

Thomas, G., \& Loxley, A. (2001). Deconstructing special education and constructing inclusion, eds: Gary Thomas, Chri--stine O'Hanlon. 1st ed. Vol. Inclusive Education ....

Tiwari, A., Das, A., \& Sharma, M. (2015). Inclusive education a "rhetoric" or "reality"? Teachers' perspectives and beliefs.

WHO, W. (2011). World disability report. Malta: World Health Organisation, The World Bank.

Winter, E. C. (2006). Preparing new teachers for inclusive schools and classrooms. Support for learning, 21(2), 85-91.

Woodcock, S., Hemmings, B., \& Kay, R. (2012). Does study of an inclusive education subject influence pre-service teachers' concerns and self-efficacy about inclusion?

Wright, C. M. (2016). Teacher Perceived Barriers to Inclusive Instructional Delivery Approaches. 